\title{
Study on the immunogenicity of pcDNA3.1(+)-cagT recombinant vector against Helicobacter pylori in BALB/c mice
}

\author{
Armita Balash $^{1}$, Abbas Doosti ${ }^{*}{ }^{\circledR}$ \\ ${ }^{1}$ Department of Biology, Faculty of Basic Sciences, Shahrekord Branch, Islamic Azad University, Shahrekord, Iran \\ ${ }^{2}$ Biotechnology Research Center, Shahrekord Branch, Islamic Azad University, Shahrekord, Iran
}

*Corresponding Author: Abbas Doosti, Address: Biotechnology Research Center, Shahrekord Branch, Islamic Azad University, Rahmatiyeh, Shahrekord, Iran, Postal box: 166 Tel: +983833361001, Fax: +983833361001;

Cell phone: +989133838830; Email: biologyshki@yahoo.com

\begin{abstract}
Background and aims: The role of Helicobacter pylori in the development of gastric ulcer and gastrointestinal cancer was identified in this study. More precisely, the study focused on the creation of a DNA vaccine based on the cagT gene of this bacterium and the investigation of its immunogenicity against $H$. pylori in infused BALB/c mice.

Materials and Methods: To this end, the pcDNA3.1(+)-cagT was prepared and transformed into Escherichia coli. Then, animals were injected with recombinant pcDNA3.1(+)-cagT plasmid, pcDNA3.1(+)-cagT + nanoparticles, and pcDNA3.1(+). After the plasmid purification and confirmation of the transformation by digestion and polymerase chain reaction (PCR), chitosan nanoparticles were synthesized using the ionic gelation method. Next, the animals were classified into three groups each including 21 mice. The injectable solutions including pcDNA3.1(+)-cagT, pcDNA3.1(+)-cagT + nanoparticles, or empty pCDNA3.1 (as a control group) were injected into the quadriceps muscle of mice, separately. Finally, the blood and tissue samples of each mouse were collected 15, 30, and 45 days after the last injection, and the expression levels of transforming growth factor-beta (TGF- $\beta 1$ ), interleukin-4 (IL-4), and interferon-gamma (IFN $\gamma$ ) were evaluated by real-time PCR.

Results: The IFN $\gamma$ and TGF- $\beta 1$ expression increased in the infused mice $(P<0.01)$ while the IL4 expression represented a significant decrease $(P<0.01)$. Moreover, the IFN $\gamma$ and IL4 expression level in pcDNA3.1 $(+)$-cag $T+$ nanoparticle significantly altered $(P<0.01)$ compared to the pcDNA3.1(+)-cagT group although the TGF- $\beta 1$ expression was not significantly different $(P=0.075)$. Contrarily, the cag $T$ gene expression in the tissue samples of both groups was significantly different 15,30 , and 45 days after the last injection $(P<0.01)$. Eventually, the expression of the cagT gene in the infused mice by pcDNA3.1(+)-cagT and in the nanoparticle group was not significantly different 45 days after the last injection $(P=0.105)$.

Conclusion: In general, the decrease of IL-4 expression was observed in the injected mice by pcDNA3.1(+)-cagT and indicated that the immune system work by a Th1 pattern. The findings showed that a pcDNA3.1(+)-cagT construct combined with chitosan nanoparticles can increase the stimulation of the immune system in an animal model and thus it can be used as an appropriate method for controlling H. pylori infection.

Keywords: H. pylori, pcDNA3.1(+)-cagT, Cytokine genes, Chitosan nanoparticles
\end{abstract}

Received: 4 September 2019, Accepted: 14 October 2019, ePublished: 29 December 2020

\section{Introduction}

Helicobacter pylori is a spiral-shaped microaerophilic Gram-negative bacterium that colonizes the luminal surface of the gastric mucosa $(1,2)$. The infection with this human pathogen causes chronic inflammation, duodenal and gastric ulcers, and gastric cancer (3). This pathogen is present in more than half of the world's population. In developing countries, $H$. pylori incidence and prevalence vary from one country to another and depends on awareness and prevention programs and the standards of health quality $(4,5)$. The prevalence of $H$. pylori infection gradually increases with age in developed countries while, in developing countries, more people are infected in childhood and a large percentage of young people also become infected after adulthood $(6,7)$. Several effectors and toxins released by $H$. pylori in the host play an important role in its pathogenicity. This human pathogen can escape from stomach acid and colonize the gastric epithelium by the possession of polar flagella, encoding cag pathogenicity island (cag PAI), vacuolating cytotoxin (Vac), and the urease enzyme thus causing tissue damage (8-10). The role of the cag PAI in this bacterium is to encode a type IV secretion system (T4SS). The entire length of the cag PAI is approximately $37 \mathrm{~kb}$ and contains 28 genes $(11,12)$. The CagT of pathogenicity island is needed to deliver CagA (cytotoxin-associated gene A) into

(C) 2020 The Author(s); Published by Shahrekord University of Medical Sciences. This is an open-access article distributed under the terms of the Creative Commons Attribution License (http://creativecommons.org/licenses/by/4.0), which permits unrestricted use, distribution, and reproduction in any medium, provided the original work is properly cited. 
gastric epithelial cells $(13,14)$.

Although several drugs have been evaluated for the treatment of $H$. pylori infection, no drug has so far been effective in treating this microorganism. The usual treatment of $H$. pylori, consisting of triple therapy using metronidazole, tetracycline, and bismuth, is not extremely costly but has a series of side effects such as oral metallic flavor associated with metronidazole consumption and increased sensitivity to light due to tetracycline and other complications such as a temporary grainy feeling of oral mucosa and teeth, constipation, diarrhea, and stool coloration $(15,16)$. Another method of treatment against this pathogen is the use of omeprazole, bismuth, and 2 antibiotics (e.g., metronidazole and tetracycline) for 2 weeks. This method of treatment is not only extremely costly but also the use of these antibiotics can cause a bad taste, diarrhea, and itching. In addition, seizures and polyneuropathy may be observed by the prolonged use of metronidazole $(17,18)$. Further, H. pylori can easily become resistant to clarithromycin and metronidazole, and it is impossible to use these antibiotics again after a course of treatment. Nowadays, the antimicrobial effects of many plant species such as garlic on $H$. pylori infection have received special attention. The association between garlic consumption and the reduction of $H$. pylori infection was emphasized (19) although, this relationship was not observed in another study (20). Vaccination is one of the most powerful health interventions and a way for increasing the function of the immune system against microbial infections such as $H$. pylori in humans $(21,22)$. Live-attenuated or killed vaccines, subunit vaccines such as DNA vaccines and recombinant vaccines have been used against $H$. pylori infection. Each kind of vaccine has some advantages and disadvantages. For example, traditional vaccines including live-attenuated or killed vaccines can transmit infectious pathogens into the vaccine recipient. Further, the production and purification of recombinant vaccines are costly, provide primarily humoral immunity, and usually require refrigeration $(23,24)$. However, DNA immunization by using genetically engineered DNA is a cost-effective strategy that can be used to efficiently stimulate humoral and cellular immune responses. It can be easily prepared, highly specific, cheap, stable at room temperature, and prevents the transmission of pathogens $(25,26)$.

Given that the $\operatorname{cag} T$ gene of $H$. pylori cag PAI is an important virulence factor in the pathogenicity of this pathogen and can stimulate the immune system of the host, the present study was performed to evaluate the immunogenicity of pcDNA3.1(+)-cagT recombinant plasmid against $H$. pylori in the infused BALB/c mice by the real-time polymerase chain reaction (RT-PCR).

\section{Materials and Methods}

\section{Recombinant vector preparation}

The $\operatorname{cag} T$ gene was synthesized and colonized into the pcDNA3.1(+) vector by Generay Biotech Company (Ltd., Shanghai, China), and pcDNA3.1(+)-cagT recombinant vector (6244 bp) was prepared accordingly. A pcDNA3.1(+) vector (Invitrogen, San Diego, CA) with a length size of $5428 \mathrm{bp}$ was used as a control plasmid for injection into BALB/c mice (Figure 1). Moreover, the Top10F' Escherichia coli was purchased from the Pasteur Institute (Tehran, Iran) and the lyophilized stock was cultured in a Luria-Bertani (LB) agar for obtaining a single colony. Then, a single colony was cultured in a $5 \mathrm{~mL}$ of $\mathrm{LB}$ broth by overnight incubation at $37^{\circ} \mathrm{C}$ and used as a host of transformation.

\section{pcDNA3.1(+)-cagT transformation}

In this study, the pcDNA3.1(+)-cagT recombinant vector was transformed into competent E. coli Top10F' cells using $\mathrm{CaCl}_{2}(0.1 \mathrm{M})$ treatment, along with heat shock for 90 seconds at $42^{\circ} \mathrm{C}$ in order to obtain sufficient plasmids for future experiments. The verity of vector transformation was confirmed by colony-PCR and then the chosen colonies containing the recombinant vector were cultured overnight in a LB broth containing $100 \mu \mathrm{g} / \mathrm{mL}$ of ampicillin antibiotic with $180 \mathrm{rpm}$ shaking at $37^{\circ} \mathrm{C}$. The plasmid purification was performed using the GeneJET Plasmid Miniprep Kit (Thermo Fisher Scientific, Freiburg, Germany), and PCR, sequencing, and enzymatic digestion with $X h o I$ and $X b a I$ restriction enzymes were done on purified plasmids for transformation confirmation. A large scale of plasmids was extracted using the MaxiPrep Plasmid Purification Kit (Qiagen; cat. \#12163) according to the manufacturer's protocol. To verify the quality and quantity of the extracted plasmid and pCDNA3.1 (empty

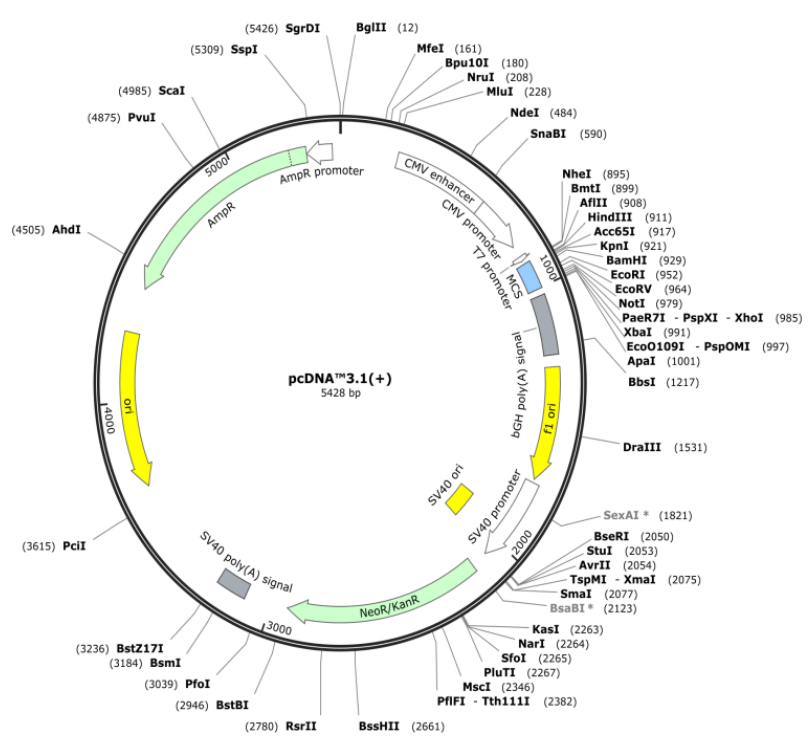

Figure 1. The map of pcDNA3.1(+) vector. 
vector), the electrophoresis on $2 \%$ agarose gel was done at a constant voltage of $80 \mathrm{~V}$ using a $1 \mathrm{~kb}$ molecular ladder, and the quantity and quality of the extracted vectors was measured at a wavelength of 260/280 nm by Thermo Scientific $^{\text {тм }}$ NanoDrop 2000 (Wilmington, DE, USA) according to the method described by Sambrook and Russell (27). After electrophoresis, the gel was stained by Gel-Red and photographed under an ultraviolet light using UVIdoc gel documentation systems (Uvitec, UK).

\section{cagT gene amplification}

For the amplification and confirmation of the presence of the $\operatorname{cag} T$ gene in the extracted plasmids, the conventional PCR assay was done in a final volume of $25 \mu \mathrm{L}$ in 0.2 $\mathrm{mL}$ micro-tubes. Specific oligonucleotide primers were designed using Gene Runner software, version 3.05, and the basic local alignment search tool (BLAST) from the NCBI GenBank data was used to compare the sequence similarity in the GenBank data (Table 1). The reaction mixture containing $1 \mu \mathrm{M}$ of each forward and reverse primer, 20-50 ng of purified plasmid DNA, 0.5 $\mu \mathrm{L}$ dNTPs, $2.5 \mathrm{U}$ Taq DNA polymerase, $1.5 \mathrm{mM} \mathrm{MgCl}_{2}$,

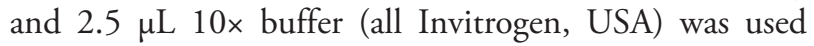
for gene amplification. Proliferation was carried out in a Mastercycler Gradient PCR (Eppendorf, Germany) with 5 minutes of initial denaturation at $94^{\circ} \mathrm{C}$, followed by 35 cycles including 1 minute of denaturation at $94^{\circ} \mathrm{C}$, 1 minute of primer annealing at $63^{\circ} \mathrm{C}, 1$ minute of elongation at $72^{\circ} \mathrm{C}$, and then a final elongation at $72^{\circ} \mathrm{C}$ for 10 minutes with a final hold at $4{ }^{\circ} \mathrm{C}$. The PCR products were visualized by agarose gel electrophoresis through a $2 \%$ agarose gel in TBE $1 \mathrm{X}$ buffer according to the abovementioned procedure.

Chitosan nanoparticles formation by the ionic gelation technique

In this study, chitosan nanoparticles were used for better absorption of the plasmid DNA in the infusion site of the animal. These nanoparticles were prepared according to the study by Calvo et al using an ionic gelation technique (28).
The chitosan powder (Sigma-Aldrich, USA) was dissolved in a $1.0 \%$ acetic acid aqueous solution $(2 \mathrm{mg} / \mathrm{mL})$ under stirring with a magnetic stirrer at $1000 \mathrm{rpm}$ for 24 hours at room temperature. The $\mathrm{pH}$ was adjusted to 5.5 with $0.5 \mathrm{M} \mathrm{NaOH}$. After the filtration of this solution, as well as the sodium tri-polyphosphate (TPP) solution $(0.7 \mathrm{mg} /$ $\mathrm{mL}$ ) through a $0.45 \mu \mathrm{m}$ filter, $20 \mathrm{~mL}$ of TPP was added extremely slowly and drop-off (1 drop every 7 seconds) to $50 \mathrm{~mL}$ of an acetic acid solution containing chitosan and was kept at $1000 \mathrm{rpm}$ for 1 hour on a magnetically stirred at room temperature. The nanoparticle suspension was centrifuged for 15 minutes at $14000 \mathrm{rpm}$ at $4^{\circ} \mathrm{C}$ and the supernatant was powdered after drying by a freezedryer (Virtis Advantage Plus freeze-dryer, SP Scientific, Warminster, USA). The physicochemical properties of chitosan nanoparticles, such as particle size and zetapotential via dispersion severity were measured using Malvern Zetasizer NANO Series NANO ZS90 (Malvern Instruments, UK). Finally, the equal value of the plasmid $(2000 \mu \mathrm{g} / \mathrm{mL}$ in PBS) and chitosan nanoparticle solution (1\%) were mixed well and placed at $55^{\circ} \mathrm{C}$ for 1 hour.

\section{Animal Groups for the Injection of the Recombinant Vector}

A total of 63 6-week-old female BALB/c mice were classified into three groups for injections (each group 21 mice) including the injections of recombinant pcDNA3.1(+)-cagT plasmid (recombinant vector), recombinant plasmids with chitosan nanoparticles (recombinant plasmid + nanoparticles), and the empty plasmid (pcDNA3.1(+) as a control group). For injections, $100 \mu \mathrm{L}$ of each infused solution including pcDNA3.1(+)cag $T$ + nanoparticles with a concentration of $1000 \mu \mathrm{g}$, $1000 \mu \mathrm{g}$ per $\mathrm{mL}$ of pcDNA3.1(+)-cagT dissolved in PBS, and empty pcDNA3.1(+) as a control group (1000 $\mu \mathrm{g}$ per $\mathrm{mL}$ of pcDNA3.1(+) vector) were prepared and injected into the quadriceps muscles of the animals of each group. The infusions were performed on days 0,7 , and 15 in all three groups of BALB/c mice. Seven mice of each group were killed and sampled 15, 30, and 45

Table 1. The applied primer sequences for q-RT-PCR

\begin{tabular}{|c|c|c|c|c|}
\hline Primers & Sequence & $\begin{array}{l}\text { Annealing temperature } \\
\left({ }^{\circ} \mathrm{C}\right)\end{array}$ & Product length (bp) & Accession number \\
\hline GAPDH & $\begin{array}{l}\text { F: 5'-TCCCGTAGACAAAATGGTGAAGG-3' } \\
\text { R: 5'-ATGTTAGTGGGGTCTCGCTCCTG-3' }\end{array}$ & 65 & 261 & XM_017321385 \\
\hline TGF- $\beta 1$ & $\begin{array}{l}\text { F: 5'-ACCGCAACAACGCCATCTATGAG-3' } \\
\text { R: 5'-GCGTATCAGTGGGGGTCAGCAG-3' }\end{array}$ & 66 & 234 & BC013738 \\
\hline IL-4 & $\begin{array}{l}\text { F: 5'-TCACAGGAGAAGGGACGCCATG-3' } \\
\text { R: 5'-TGGACTTGGACTCATTCATGGTGC-3' }\end{array}$ & 67 & 246 & NM_021283 \\
\hline $\mathrm{IFN} \gamma$ & $\begin{array}{l}\text { F: 5'-GCCTAGCTCTGAGACAATGAACG-3' } \\
\text { R: 5'-GCCAGTTCCTCCAGATATCCAAG-3' }\end{array}$ & 64 & 188 & M28621 \\
\hline $\operatorname{cag} T$ & $\begin{array}{l}\text { F: 5'-TGAGAGCAAGTGTTTTAATCGGTG-3' } \\
\text { R: 5'-TGAATGGTGTGTCTTTGAGTTTGTC-3' }\end{array}$ & 63 & 177 & JQ685147 \\
\hline
\end{tabular}

Note. q-RT-PCR: Quantitative real-time polymerase chain reaction; GAPDH: Glyceraldehyde 3-phosphate dehydrogenase; TGF- $\beta 1$ : Transforming growth factorbeta; IL-4: Interleukin-4; IFN $\gamma$ : Interferon-gamma; 
days after the last injection. After anesthesia, the whole blood specimens $(1.5 \mathrm{~mL})$ were taken from the heart of each mouse at each sampling stage and transferred into ethylenediaminetetraacetic acid as an anticoagulant. Then, the quadriceps muscle of the mice was removed and the injection site of muscle tissues was isolated as well.

\section{RT-PCR assay}

Total RNA was isolated from $100 \mathrm{mg}$ of each tissue sample or $100 \mu \mathrm{L}$ of a buffy coat of blood specimens, immediately using the TRIzol reagent (Invitrogen, USA) according to the manufacturer's specifications. The absorbance of the extracted RNA samples was measured at a wavelength of 260-280 nm, and cDNA samples were synthesized by a cDNA synthesis kit (Takara, Kyoto, Japan) using specific primers or mixing them with an oligo $(\mathrm{dT})$ primer according to the manufacturer's instructions. The mixture was heated to $85^{\circ} \mathrm{C}$ for 5 seconds and then incubated at $42^{\circ} \mathrm{C}$ for 15 minutes, and the inactivation of reverse transcriptase was done for 5 minutes at $85^{\circ} \mathrm{C}$.

Specific oligonucleotide primers were designed using Gene Runner software, version 3.05 (Hastings Software Inc. Hastings, NY, USA) and the BLAST of GenBank data (Table 1). The expression levels of cytokine genes, including TGF- $\beta 1$, interleukin- 4 (IL- 4 ), and IFN $\gamma$ were evaluated by comparing to GAPDH (glyceraldehyde 3-phosphate dehydrogenase) as an internal control and $\operatorname{cag} T$ as a target gene of the manipulated vector in q-RT-PCR. The cDNA samples (50 ng) in appropriate dilutions $(1: 10)$ were added in a final volume of $20 \mu \mathrm{L}$, containing 1× SYBR Green PCR Master Mix (Toyobo, Japan) and $1 \mu \mathrm{L}$ of each primer $(2 \mu \mathrm{M})$. The temperature cycling was including initial denaturation at $95^{\circ} \mathrm{C}$ for 5 minutes, followed by 40 cycles of denaturation at $95^{\circ} \mathrm{C}$ for 15 seconds, primer annealing at the optimal temperature according to Table 1 for 20 seconds, and extension at $72^{\circ} \mathrm{C}$ for 30 seconds. All reactions were done in triplicate, and q-RT-PCR was monitored by measuring the fluorescence at the end of the annealing phase of each cycle. The relative levels of gene expression were revealed by the standard curve method, and the cycle of the threshold $(\mathrm{Ct})$ values of the target and the reference genes was analyzed by the comparative $\mathrm{Ct}\left(2^{-\Delta \Delta \mathrm{Ct}}\right)$ method. The DNA melting-curve analysis was performed by the Corbett Rotor-Gene 6000 machine by holding the reaction mixtures at $95^{\circ} \mathrm{C}$ for 60 seconds and decreasing it to $40^{\circ} \mathrm{C}$ at a transition rate of $0.1^{\circ} \mathrm{C} /$ second for the detection of fluorescence absorption at a wavelength of $640 \mathrm{~nm}$.

\section{Statistical analysis}

The results were analyzed by Social Sciences software (SPSS, Inc., Chicago, IL, USA), version 20 using the independent t-test to examine the relationship between groups and the significance of the data. All data were considered statistically significant at a $P<0.05$.
Results

Verifying the Inserted Gene in the Recombinant Vector The recombinant pcDNA3.1(+)-cagT vector was successfully transformed into competent $E$. coli, and the accuracy of the transformation on the extracted plasmids and formation of the final construct were determined by enzymatic digestion and PCR. The PCR showed the presence of the inserted gene in the vector, and the digestion of the pcDNA3.1(+)-cagT recombinant vector by $X h o I$ and $X b a I$ restriction endonucleases on $2 \%$ agarose gel electrophoresis revealed two fragments including 5428 and 855 bp as pcDNA3.1(+) and the cagT gene, respectively (Figure 2 ).

\section{Physical characteristics of chitosan nanoparticles}

The chitosan-DNA nanoparticle characteristics, including the particle size and zeta-potential, were determined using the dynamic light scattering method and Malvern Zetasizer Nano-ZS (ZEN3600), respectively, showing that $98.6 \%$ of these particles had a $133.4 \mathrm{~nm}$ diameter. Additionally, the velocity distribution of the nanoparticle movement was measured by the dynamic fluctuations of light scattering intensity at $25^{\circ} \mathrm{C}$ and a wavelength of 633 nm (Figure 3).

The investigation of the appearance of chitosan nanoparticles by the SEM showed that the nanoparticles had a homogeneous spherical shape with smooth edges (Figure 4).

\section{Gene expression analysis}

The gene expression analysis by RT-PCR using REST 2009 software indicated that IFN $\gamma$ and TGF- $\beta 1$ expression levels with the recombinant vector increased in the infused group $(P<0.01)$ while the IL4 expression demonstrated

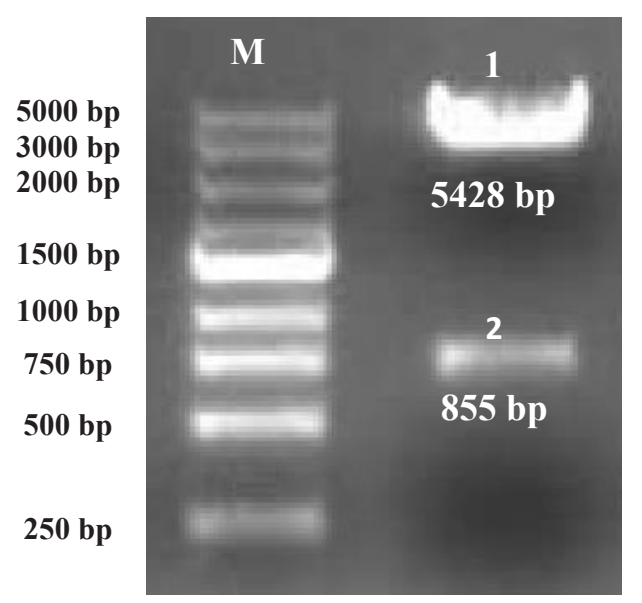

Figure 2. The restriction digestion of pcDNA3.1(+)-cagT recombinant plasmid constructs on $2 \%$ agarose gel electrophoresis. Note. Lane $M$ is the $1 \mathrm{~kb}$ DNA ladder (Thermo Fisher Scientific, Freiburg, Germany). Fragments 1 and 2 were pcDNA3.1(+) vector and the exited cagT gene, respectively. 

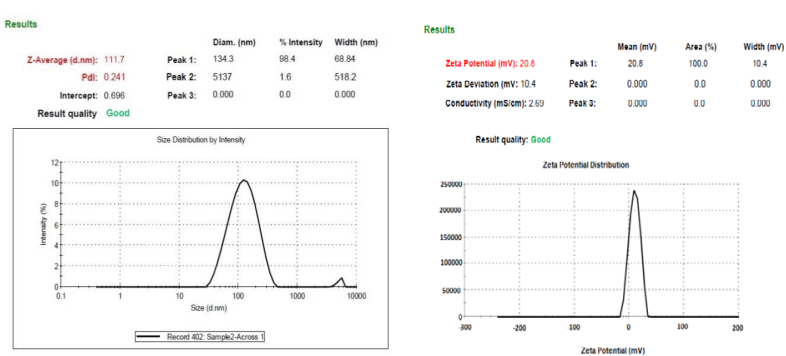

Figure 3.Zeta-potential Distribution of Chitosan Nanoparticles

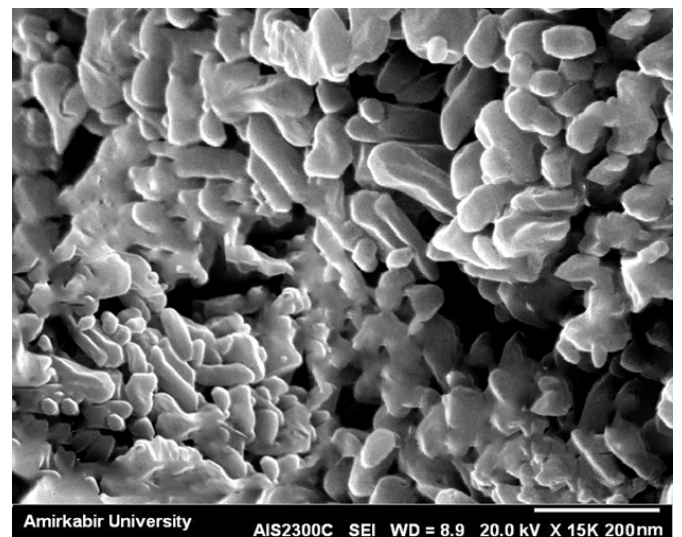

Figure 4. The image of chitosan nanoparticles by SEM. Note. SEM: Scanning electron microscope.

a significant decrease $(P<0.01)$. The comparison of the expression level of cytokine genes in the blood of infused $\mathrm{BALB} / \mathrm{c}$ mice represented that the expression level of IFN $\gamma$ and IL4 genes in the pcDNA3.1(+)-cagT + nanoparticle group significantly differed compared with the injected BALB/c mice by the pcDNA3.1(+)-cagT group $(P<0.01)$ although the expression of the TGF- $\beta 1$ gene in these groups displayed no significant difference $(P=0.075)$, the related data of which are illustrated in Figure 5.

Based on the comparison of $\operatorname{cag} T$ gene expression in the tissue samples of the infused animal by pcDNA3.1(+)cag $T+$ nanoparticle in different time intervals after the last injection (Figure 6), the expression of the cagT gene was significantly different at days 15,15 , and 30 compared to days 30,45 , and 45 , respectively $(P<0.01)$. In addition, the cagT gene expression level in pcDNA3.1(+)-cagT (without nanoparticles) on day 15 compared with days 30 and 45, and on day 30 compared to day 45 was significantly different $(P<0.01)$.

Moreover, the expression level of the target gene in the tissue samples of infused mice by pcDNA3.1(+)-cagT in each day was significantly different $(P<0.01)$ after the last injection (Figure 7).

Similarly, the expression level of the $\operatorname{cag} T$ gene in the infused $\mathrm{BALB} / \mathrm{c}$ mice by pcDNA3.1(+)-cagT and pcDNA3.1(+)-cag $T+$ nanoparticle groups on days 15 and 30 was significantly different $(P<0.01)$ although at day 45 it was not significantly different $(P=0.105)$ after the last injection (Figure 7).

\section{Discussion}

Helicobacter pylori infection is highly common worldwide, and the prevention of primary gastrointestinal infections by a suitable vaccine, especially using DNA vaccine is attractive $(29,30)$. One of the effective virulence factors in $H$. pylori infection is the $\operatorname{cag} T$ gene thus the recombinant pcDNA3.1(+)-cagT DNA vector was created based on this gene in this study. After the vaccination of BALB/c mice, its immunogenicity against this pathogen was evaluated by the RT-PCR. The BALB/c mice were classified into three groups of pcDNA3.1(+)-cagT, pcDNA3.1(+)-cagT + nanoparticle, and controls (pcDNA3.1(+), the empty vector). Injections into the quadriceps muscle of mice were performed after the preparation of chitosan nanoparticles by the ionic gelation method. The mice were killed 15 , 30 , and 45 days after the last injection, and the blood and tissue samples of infused mice were collected. Then, the total RNA was extracted from each sample, and cDNA was synthesized as well. The expression level of cytokines including TGF- $\beta 1$, IL-4, and IFN $\gamma$, as well as cag T (as a target gene of the recombinant vector) against $H$. pylori infection was evaluated using the RT-PCR method. The results of cytokine gene expression showed that the expression of IFN $\gamma$ and TGF- $\beta 1$ genes in the infused animals increased $(P<0.01)$ but the IL4 expression decreased significantly $(P<0.01)$. The comparison of the gene expression levels

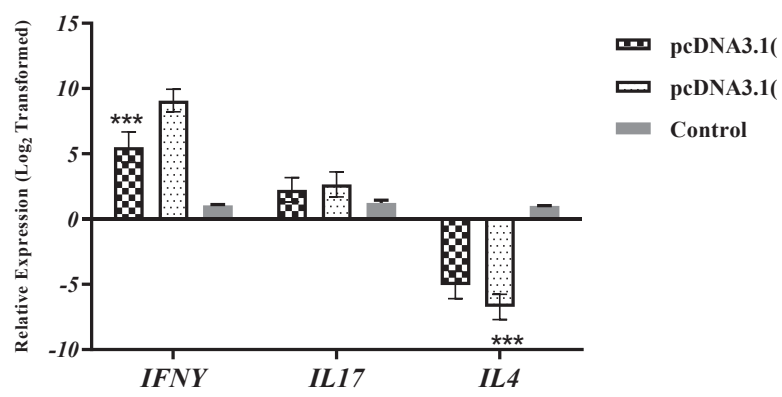

Figure 5. Comparison of the expression pattern of all three cytokines (i.e., IL4, TGF- $\beta 1$, and IFN $\gamma$ ) in injected BALB/c mice by pcDNA3.1(+)-cagT + nanoparticle and pcDNA3.1(+)-cagT compared with the control (infused by empty pcDNA3.1(+) vector).
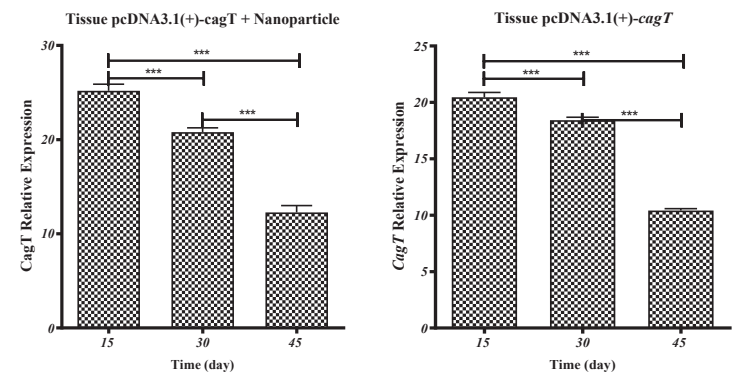

Figure 6. The comparison of the cagT gene expression in the infused BALB/c mice tissue by pcDNA3.1(+)-cagT + nanoparticle (left) and pcDNA3.1(+)-cagT (right) in different time intervals. 


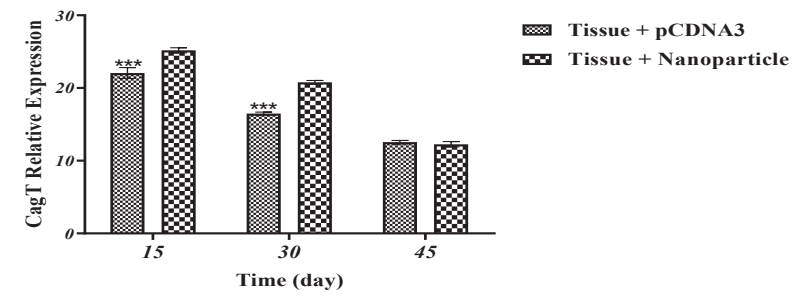

Figure 7. The comparison of the cagT gene expression in injected groups by pcDNA3.1(+)-cagT and pcDNA3.1(+)-cagT + nanoparticle at different times after the last injection.

of these cytokines in blood specimens revealed that IFN $\gamma$ and IL4 genes in the pcDNA3.1(+)-cagT + nanoparticle group were significantly different $(P<0.01)$ compared to the pcDNA3.1(+)-cagT group although the expression level of the TGF- $\beta 1$ gene was not significantly different $(P>0.075)$. In tissue samples, the comparison of $\mathrm{cag} T$ gene expression in both pcDNA3.1(+)-cagT + nanoparticle and pcDNA3.1(+)-cagT groups were significantly different at different time intervals after the last injection $(P<0.01)$. Further, the expression level of the $\operatorname{cag} T$ gene in infused $\mathrm{BALB} / \mathrm{c}$ mice by a recombinant plasmid with and without nanoparticles at 45 days after the last injection was not significantly different $(P>0.105)$.

In recent decades, various studies have focused on finding an appropriate vaccine to immunize and prevent H. pylori infection $(24,31)$. In a study by Sun et al, an H. pylori neutrophil-activating protein gene was cloned into the $\mathrm{pBT}$ vector and then sub-cloned into the pIRES eukaryotic expression vector. After transformation into live attenuated Salmonella typhimurium, the vector was used as an oral recombinant DNA vaccine against $H$. pylori infection. Their findings indicated that pIRES-NAP recombinant plasmid induced a specific immune response in animal models (32). Their method was somewhat similar to the present study, but in our study, the pcDNA3.1(+)-cagT construct was created and its efficiency for inducing the immune system by the investigations of TGF- $\beta 1$, IL- 4 , and IFN $\gamma$ cytokine genes was observed using molecular techniques against $H$. pylori pathogen in an animal model. Najar Peerayeh et al examined the colonies and HpaA gene expression of $H$. pylori, and this gene was amplified and cloned into the PET28a propagating vector and transformed into BL21DE2 E. coli. The PET-HPa-BL21 was created and the expression of the recombinant protein was confirmed by sodium dodecyl-sulfate polyacrylamide gel electrophoresis and the western blot. Then, the immunogenic activity of the $H p a A$ gene against $H$. pylori cells was detected by the antipolyclonal antibody. The prokaryotic expression system PET-HPa-BL21 that expressed the HPaA fusion protein showed a satisfactory immunogenic activity that could be an appropriate candidate against $H$. pylori (33). In their research, the PET28a vector expressing the $H p a A$ gene was created while, in the present study, the pcDNA3.1(+)-cagT construct with or without nanoparticles was prepared and used against $H$. pylori. Finally, the expression of TGF- $\beta 1$, IL-4, and IFN $\gamma$ genes, as well as cagT (as a target gene) was investigated by the RT-PCR after the infusion into the $\mathrm{BALB} / \mathrm{c}$ mice, and the appropriate expression with sufficient immune stimulation was observed accordingly. In another study by $\mathrm{Gu}$ et al, the expressing recombinant urease subunit $\mathrm{B}$ by transforming the urease subunit $\mathrm{B}$ of H. pylori into Lactococcus lactis was prepared and used as an oral vaccine in mice against $H$. pylori. Based on their results, a specific immunoglobulin $\mathrm{G}$ of urease $\mathrm{B}$ was produced in the injected mice which stopped the infection of $H$. pylori in the stomach (34). Our work was similar to their study, except that the pcDNA3.1(+)-cagT recombinant vector, alone or in combination with chitosan nanoparticles, was infused into the quadriceps femoris muscle.

In a study by Doosti the Omp31 gene of Brucella melitensis was cloned into pcDNA3.1 to create an Omp31pcDNA3.1 construct. After the immunization of BALB/c mice, the Th-1 cell reaction was observed in mice (35). In a different work by Doosti et al, the heavy chain of Clostridial botulinum neurotoxin was cloned into $E$. coli by the T/A cloning method and its validity was confirmed by the PCR. Based on their results, this construct gene could be used to produce a botulinum neurotoxin vaccine (36).

The antigenic region of the cagA gene of $H$. pylori was amplified by the PCR and subcloned into the PET32a prokaryotic vector. The PET32a-cagA construct was transferred into E. coli BL21 (DE3) PLYSS. The expressed protein was purified by the chromatography column, enzymatic digestion, the PCR, and sequencing and showed that the antigenic region of the recombinant CagA protein could be selected as the suitable candidate for the gene vaccine. The difference between their research and the present study was the kind of applied gene and vector for vaccination (37). In a study by Farjadi et al, the PLYSS strain BL21 (DE3) was used and PET32a-cagA was produced and applied for vaccination while, in the present work, the pcDNA3.1(+)-cagT was created and transferred into E. coli Top10 strain as a host, and then this recombinant vector was infused into the mice, suggesting that pcDNA3.1(+)-cagT could be used as a suitable candidate for vaccination against $H$. pylori.

In another study, the UreB (urease B) gene of $H$. pylori was fused with IL-2 as the mucosal adjuvant and cloned into Lactococcus lactis and used for the injection of mice. Their findings represented the production of anti-UreB antibody and more cytokines such as IFN- $\gamma$, IL- 4 , and IL17 in the infused mice and revealed that this recombinant L. lactis expressing UreB-IL-2 can be potentially used as an edible vaccine for controlling $H$. pylori infection (38). In the present study, the expression level of IFN $\gamma$ and TGF- $\beta 1$ genes increased after the injection of mice by the pcDNA3.1(+)-cagT recombinant vector although the IL4 
expression indicated a significant decrease.

\section{Conclusion}

In conclusion, the expression of IFN $\gamma$ and TGF- $\beta 1$ significantly increased in the blood specimens of the infused BALB/c mice by pcDNA3.1 (+)-cagT + nanoparticle and pcDNA3.1(+)-cagT, but the expression of IL-4 represented a significant decrease. In addition, a decrease was observed in the $\operatorname{cag} T$ gene expression in the tissue specimens of mice 45 days after the last injection. Considering that the IL- 4 is the most prominent cytokine of Th2, a reduction of IL- 4 can indicate the non-response of Th2 in BALB/c mice, which confirms the response of the immune system as a Th1 pattern. Further, the findings demonstrated that the application of chitosan nanoparticles together with recombinant plasmid increased the expression of ILs in injected mice. In future studies, the produced pcDNA3.1 (+)-cagT construct could be used as a suitable marker for biological and pathological investigation and drugdiscovery in eukaryotic systems, biomarker discovery, and vaccination and prevention in human models.

Conflict of Interests

The authors declare that they have no conflict of interests.

\section{Ethical Approval}

This study was approved by the Research Ethics Committees of the Deputy of the Research and Technology of Islamic Azad University of Shahrekord Branch, Shahrekord, Iran on August 30 ${ }^{\text {th }}, 2016$ (The ethics code: IR.IAU.SHK.REC.1395.334).

\section{Authors Contribution}

Conception and design, acquisition of data, analysis and interpretation of data done by $\mathrm{AD}$. Drafting of the manuscript performed by $A D$ and $A B$. Critical revision of the manuscript for important intellectual content and statistical analysis done by AD. $\mathrm{AB}$ and $\mathrm{AD}$ contributed in all microbial tests, animal injections and molecular techniques. The final draft approved by AD.

\section{Funding/Support}

None.

\section{Acknowledgements}

This article was obtained from the MSc thesis with grant number: 32462 on August $30^{\text {th }}, 2016$ and the authors would like to extend sincerest thanks and appreciation to the Research Deputy and the Biotechnology Research Center of the Islamic Azad University of Shahrekord Branch for their cooperation.

\section{References}

1. Tseng YY, Liou JM, Hsu TL, Cheng WC, Wu MS, Wong CH. Development of bacterial transglycosylase inhibitors as new antibiotics: moenomycin A treatment for drug-resistant Helicobacter pylori. Bioorg Med Chem Lett. 2014;24(11):24124. doi: 10.1016/j.bmcl.2014.04.041.

2. Ferwana M, Abdulmajeed I, Alhajiahmed A, Madani W, Firwana B, Hasan R, et al. Accuracy of urea breath test in Helicobacter pylori infection: meta-analysis. World J Gastroenterol. 2015;21(4):1305-14. doi: 10.3748/wjg.v21. i4.1305.

3. Graham DY. History of Helicobacter pylori, duodenal ulcer, gastric ulcer and gastric cancer. World J Gastroenterol. 2014;20(18):5191-204. doi: 10.3748/wjg.v20.i18.5191.

4. Garza-González E, Perez-Perez Gl, Maldonado-Garza HJ, Bosques-Padilla FJ. A review of Helicobacter pylori diagnosis, treatment, and methods to detect eradication. World J Gastroenterol. 2014;20(6):1438-49. doi: 10.3748/wjg.v20. i6.1438.

5. Patel SK, Pratap CB, Jain AK, Gulati AK, Nath G. Diagnosis of Helicobacter pylori: what should be the gold standard? World J Gastroenterol. 2014;20(36):12847-59. doi: 10.3748/wjg. v20.i36.12847.

6. Ghorbani-Dalini S, Kargar M, Doosti A, Abbasi P, Souod N. Optimization of real-time PCR method to assess the direct sensitivity of clarithromycin in Helicobacter pylori. Journal of Microbial World. 2009;2(3):149-54. [Persian].

7. Morais S, Ferro A, Bastos A, Castro C, Lunet N, Peleteiro B. Trends in gastric cancer mortality and in the prevalence of Helicobacter pylori infection in Portugal. Eur J Cancer Prev. 2016;25(4):275-81. doi: 10.1097/cej.0000000000000183.

8. Dunne C, Dolan B, Clyne M. Factors that mediate colonization of the human stomach by Helicobacter pylori. World J Gastroenterol. 2014;20(19):5610-24. doi: 10.3748/wjg.v20. i19.5610.

9. Huang JY, Sweeney EG, Sigal M, Zhang HC, Remington SJ, Cantrell MA, et al. Chemodetection and destruction of host urea allows Helicobacter pylori to locate the epithelium. Cell Host Microbe. 2015;18(2):147-56. doi: 10.1016/j. chom.2015.07.002.

10. Bagheri N, Azadegan-Dehkordi F, Rafieian-Kopaei M, Rahimian G, Asadi-Samani M, Shirzad H. Clinical relevance of Helicobacter pylori virulence factors in Iranian patients with gastrointestinal diseases. Microb Pathog. 2016;100:15462. doi: 10.1016/j.micpath.2016.09.016.

11. Olbermann $\mathrm{P}$, Josenhans $\mathrm{C}$, Moodley $\mathrm{Y}$, Uhr $\mathrm{M}$, Stamer C, Vauterin $M$, et al. A global overview of the genetic and functional diversity in the Helicobacter pylori cag pathogenicity Island. PLoS Genet. 2010;6(8):e1001069. doi: 10.1371/journal.pgen.1001069.

12. Nijevitch AA, Idrisov B, Kuchina E, Bilalov F, Akhmadeeva EN. An adaptive evolution of Helicobacter pylori: role of the CagA presence in the outcome of $\mathrm{H}$. pylori eradication in children. Pediatr Therapeut. 2013;3(4):164. doi: 10.4172/21610665.1000164.

13. Roesler BM, Rabelo-Gonçalves EM, Zeitune JM. Virulence factors of Helicobacter pylori: a review. Clin Med Insights Gastroenterol. 2014;7:9-17. doi: 10.4137/CGast.S13760.

14. Gopal GJ, Pal J, Kumar A, Mukhopadhyay G. C-terminal domain of CagX is responsible for its interaction with CagT protein of Helicobacter pylori type IV secretion system. Biochem Biophys Res Commun. 2015;456(1):98-103. doi: 10.1016/j.bbrc.2014.11.041.

15. Fallone CA, Chiba N, van Zanten SV, Fischbach L, Gisbert JP, Hunt RH, et al. The Toronto consensus for the treatment of Helicobacter pylori infection in adults. Gastroenterology. 2016;151(1):51-69.e14. doi: 10.1053/j.gastro.2016.04.006.

16. Safavi M, Sabourian R, Foroumadi A. Treatment of Helicobacter pylori infection: current and future insights. World J Clin Cases. 2016;4(1):5-19. doi: 10.12998/wjcc.v4.i1.5

17. Gisbert JP, Perez-Aisa A, Rodrigo L, Molina-Infante J, Modolell $\mathrm{I}$, Bermejo F, et al. Third-line rescue therapy with bismuthcontaining quadruple regimen after failure of two treatments (with clarithromycin and levofloxacin) for H. pylori infection. Dig Dis Sci. 2014;59(2):383-9. doi: 10.1007/s10620-0132900-x.

18. Malfertheiner P, Megraud F, O'Morain CA, Gisbert JP, Kuipers 
EJ, Axon AT, et al. Management of Helicobacter pylori infection-the Maastricht V/Florence consensus report. Gut. 2017;66(1):6-30. doi: 10.1136/gutjnl-2016-312288.

19. Ghobeh M, Shaker Hosseini R, Navaii L, Mirsatari D, Rashid Khani B, Norouzi MF. Evaluation of garlic effect on Helicobacter pylori eradication. Journal of Shahid Sadoughi University of Medical Sciences. 2010;18(4):337-47. [Persian].

20. Nicastro HL, Ross SA, Milner JA. Garlic and onions: their cancer prevention properties. Cancer Prev Res (Phila). 2015;8(3):181-9. doi: 10.1158/1940-6207.capr-14-0172.

21. Hongying F, Xianbo W, Fang Y, Yang B, Beiguo L. Oral immunization with recombinant Lactobacillus acidophilus expressing the adhesin Hp0410 of Helicobacter pylori induces mucosal and systemic immune responses. Clin Vaccine Immunol. 2014;21(2):126-32. doi: 10.1128/cvi.00434-13.

22. McFarland LV, Huang Y, Wang L, Malfertheiner P. Systematic review and meta-analysis: multi-strain probiotics as adjunct therapy for Helicobacter pylori eradication and prevention of adverse events. United European Gastroenterol J. 2016;4(4):546-61. doi: 10.1177/2050640615617358.

23. Wang B, Pan X, Wang H, Zhou Y, Zhu J, Yang J, et al. Immunological response of recombinant $H$. pylori multiepitope vaccine with different vaccination strategies. Int J Clin Exp Pathol. 2014;7(10):6559-66.

24. Eslami E, Doosti A. Cloning and expression study of the hcpD gene of Helicobacter pylori. Journal of Ardabil University of Medical Sciences. 2017;17(1):46-57. [Persian].

25. Khan KH. DNA vaccines: roles against diseases. Germs. 2013;3(1):26-35. doi: 10.11599/germs.2013.1034.

26. Doosti A, Ghasemi-Dehkordi P, Kargar M, Sharifi A. Generation of divalent DNA vaccine based on p39 and shiga-like toxin 2 (stx2) genes. Genetika Belgrade. 2015;47(2):499-507.

27. Sambrook J, Russell DW. Molecular cloning: a laboratory manual. 3rd ed. New York: Cold Spring Harbor Laboratory Press; 2001. p. 148-90.

28. Calvo P, Remuñán-López C, Vila-Jato JL, Alonso MJ. Novel hydrophilic chitosan-polyethylene oxide nanoparticles as protein carriers. J Appl Polym Sci. 1997;63(1):125-32. doi: $\quad$ 10.1002/(SICI)1097-4628(19970103)63:1<125::AIDAPP13>3.0.CO;2-4.
29. Kargar M, Baghernejad M, Doosti A, Ghorbani-Dalini S. Clarithromycin resistance and 23S rRNA mutations in Helicobacter pylori isolates in Iran. Afr J Microbiol Res. 2011;5(8):853-6. doi: 10.5897/ajmr10.120.

30. Milani M, Sharifi Y, Rahmati-Yamchi M, Somi MH, Akbarzadeh A. Immunology and vaccines and nanovaccines for Helicobacter pylori infection. Expert Rev Vaccines. 2015;14(6):833-40. doi: 10.1586/14760584.2015.1008460.

31. Hussain SA, Hamid S. Helicobacter pylori in humans: where are we now? Adv Biomed Res. 2014;3:63. doi: 10.4103/22779175.125844.

32. Sun B, Li ZS, Tu ZX, Xu GM, Du YQ. Construction of an oral recombinant DNA vaccine from $H$. pylori neutrophil activating protein and its immunogenicity. World J Gastroenterol. 2006;12(43):7042-6. doi: 10.3748/wjg.v12.i43.7042.

33. Najar Peerayeh S, Atoofi J, Hoseinkhani S, Farshchian M. Cloning and expression of Helicobacter pylori HpaA gene. Cell J. 2009;11(3):273-6. [Persian].

34. Gu Q, Song D, Zhu M. Oral vaccination of mice against Helicobacter pylori with recombinant Lactococcus lactis expressing urease subunit B. FEMS Immunol Med Microbiol. 2009;56(3):197-203. doi: 10.1111/j.1574695X.2009.00566.x.

35. Doosti A. Cloning of the gene encoding neurotoxin heavy chain of Clostridium botulinum in E. coli. Journal of Microbial World. 2012;5(3-4):77-84. [Persian].

36. Doosti A, Ghasemi-Dehkordi P, Javadi GR, Sardari S, Shokrgozar MA. DNA vaccine encoding the Omp31 gene of Brucella melitensis induces protective immunity in BALB/C mice. Res J Biol Sci. 2009;4(1):126-31.

37. Farjadi V, Abtahi H, Zolfaghari MR, Soufian S, Hasanzadeh L. Expression, purification and evaluation of antigenicity of CagA antigenic fragment of Helicobacter pylori. Jundishapur J Microbiol. 2013;6(9):e7367. doi: 10.5812/jjm.7367.

38. Zhang HX, Qiu YY, Zhao YH, Liu XT, Liu M, Yu AL. Immunogenicity of oral vaccination with Lactococcus lactis derived vaccine candidate antigen (UreB) of Helicobacter pylori fused with the human interleukin 2 as adjuvant. Mol Cell Probes. 2014;28(1):25-30. doi: 10.1016/j.mcp.2013.08.003. 